\title{
Dinamika Psikologis Pasangan Suami Istri yang Belum Memiliki Anak
}

\author{
Hermi Pasmawati ${ }^{1} \&$ Feny Maria ${ }^{2}$ \\ 1,2 Institut Agama Islam Negeri Bengkulu \\ e-mail: hermipasmawati@iainbengkulu.ac.id
}

\begin{abstract}
Abstrak. Children are a gift and at the same time trust from Allah SWT. After marriage one of the things that awaited by the couple is the presence of a baby in the middle of the family, but not a few phenomena in the field of couples who have not been blessed with children, this condition causes feelings of anxiety, because of the demands of the couple or family of the couple and comparison with other couples who have have children, this condition certainly provides its own psychological effects for couples. Based on this phenomenon, there are two problems examined in this paper, namely; 1) What is the psychological dynamics of a married couple who do not have children, 2). How are the efforts made by married couples in overcoming psychological problems. This type of research used in this research is descriptive qualitative with a case study approach. There were ten informants in the study, consisting of six husband and wife couples who did not have children and four supporting informants. The results found that (1) psychological dynamics that occur in married couples who do not have children in East Kikim sub-district, viewed from the emotional aspects of changing at the beginning of marriage, busband and wife do not feel there is a burden, but with increasing age of marriage and not yet blessed with children, making them feel anxious and worried, even because they have been married for decades and still do not have children, so they surrender. Seen from the aspect of adjustment, there are several couples in interacting with the family environment, neighbors or the community does not experience difficulties, but there are also those who experience difficulties in adjusting. Viewed from the aspect of motivation there are some couples who get support and advice from family and neighbors, but there are also those who only support each other between the husband and wife. positive activities such as religious activities, convince yourself that this condition can certainly be bypassed and then do activities that you like, while also doing medical or herbal treatment.
\end{abstract}

Key Words: psychological dynamics.

Abstrak. Anak adalah karunia dan sekaligus amanah dari Allah SWT. Setelah menikah salah satu hal yang dinantikan oleh pasangan adalah kehadiran buah hati di tengah keluarga, namun tidak sedikit fenomena di lapangan pasangan yang belum dikaruniai anak, kondisi ini menimbulkan perasaan cemas, karena adanya tuntutan dari pasangan maupun keluarga pasangan dan perbandingan dengan pasangan lain yang sudah memiliki anak, kondisi ini tentunya memberikan efek psikologis tersendiri bagi pasangan. Berdasarkan fenomena ini, Ada dua persoalan yang dikaji dalam tulisan ini, yaitu; 1) Bagaimana dinamika psikologis pasangan suami istri yang belum memiliki anak, 2). Bagaimana upaya yang dilakukan pasangan suami istri dalam mengatasi masalah psikologis. Jenis penelitian yang digunakan dalam penelitian ini deskriptif kualitatif dengan pendekatan studi kasus. Informan penelitian berjumlah sepuluh orang, yang terdiri atas enam pasang suami isteri yang belum memiliki anak dan empat orang informan pendukung. Hasil penelitian ditemukan bahwa (1) dinamika psikologis yang terjadi pada pasangan suami istri yang belum memiliki anak di kecamatan Kikim Timur, dilihat dari aspek emosi mengalami perubahan pada awal pernikahan, pasangan suami istri belum merasa ada beban, namun dengan bertambahnya usia pernikahan dan belum juga dikaruniai anak, membuat mereka merasa cemas dan khawatir, bahkan karena sudah berpuluh-puluh tahun menikah belum juga memiliki keturunan, sehingga mereka pasrah. Dilihat dari aspek penyesuaian diri ada beberapa pasangan suami istri dalam berinteraksi dengan lingkungan keluarga, tetangga atau masyarakat tidak mengalami kesulitan, akan tetapi ada juga yang mengalami kesulitan dalam menyesuaikan diri. Dilihat dari aspek motivasi ada beberapa pasangan suami istri yang mendapatkan dukungan dan saran dari keluarga maupun tetangga, akan tetapi ada juga yang hanya saling mendukung antar pasangan suami istri tersebut (2) Upaya yang dilakukan pasangan suami istri dalam mengatasi masalah psikologis melakukan kegiatan-kegiatan yang positif seperti mengikuti kegiatan keagamaan, meyakinkan diri bahwa kondisi ini pasti bisa dilewati kemudian melakukan kegiatan yang disukai, selain itu juga melakukan pengobatan medis maupun herbal.

Kata Kunci: Dinamika Psikologis 


\section{PENDAHULUAN}

Pada Manusia mempunyai jiwa yang merupakan sistem (disebut sistem nafsani) yang terdiri dari 'Aql (akal) yang berfungsi untuk berpikir dan membedakan yang buruk dan baik.Qalb (hati) yang berfungsi untuk memimpin kerja jiwa manusia dan memahami realita, ketika akal mengalami kesulitan. Bashira disebut juga sebagai nurani, dari kata nur, dalam bahasa Indonesia menjadi hati nurani (Faizah \& Efendi, 2006). Syahwat adalah motif kepada tingkah laku.Semua manusia memiliki syahwat terhadap lawan jenis, bangga terhadap anak-anak, menyukai benda berharga dan lain sebagainya.Jadi, didalam jiwa manusia terdapat juga syahwat terhadap lawan jenis.Oleh kareana itu untuk memenuhi syahwat terhadap lawan jenis ini, maka manusia melakukan yang namanya pernikahan agar tidak menimbulkan zina.

Menurut Undang-Undang Perkawinan, Nomor. 1 Tahun 1974, yang dimaksudkan dengan perkawinan ialah ikatan lahir batin antara seorang pria dan seorang wanita sebagai suami istri dengan tujuan membentuk keluarga (rumah tangga) yang bahagia dan kekal berdasarkan Ketuhanan Yang Maha Esa (Walgito, 2017). Pernikahan juga merupakan awal dari gerbang utama yang harus dilewati oleh pasangan suami istri dalam membentuk keluarga sakinah, mawadah, warahmah sebagaimana yang diajarkan dalam agama Islam (Bambang dan Ismaya, 2015). Oleh karena itu sudah menjadi kodratnya bahwa manusia diciptakan Allah untuk saling berpasangan atau memiliki pasangan hidup dan membangun keluarga yang harmonis karena adanya kesadaran untuk bersama saling membangun nilai ibadah sekaligus memenuhi kebutuhan masing-masing dalam pasangan suami istri, sehingga terbentuk keluarga sakinah yang diliputi rasa saling kasih sayang.

Perkawinan dalam Islam merupakan suatu bentuk ibadah, ia dimaksudkan untuk melestarikan keturunan. Di samping itu, perkawinan juga untuk memberikan kesenangan biologis kepada suami istri agar memperoleh kebahagian secara lahir dan batin. Secara sunnatullah, jika tidak ada faktor penghalang, beberapa waktu setelah berhubungan intim sperma dan ovum akan bertemu maka terjadilah pembuahan (Muni dan Al-Hafidzoh, 2010). Dalam hal ini adapun tujuan dari perkawinan adalah selain melaksanakan sunnah Nabi guna mendapatkan ridho Allah SWT. Dan juga untuk mempersatuka keluarga dan meneruskan keturunan. Anak bisa dikatakan sebagai sumber kebahagian bagi suami istri. Anak mempunyai arti penting dalam perkawinan, karena merupakan sebagai penyejuk hati dalam rumha tangga dan sebuah amanah yang harus dijaga oleh orangtua (Yandri \& Juliawati, 2019), hal ini seperti firman Allah swt yang artinya: "Harta dan anak-anak adalah perhiasan kehidupan dunia tetapi amalan-amalan yang kekal lagi saleh adalah lebih baik pahalanya di sisi Tuhanmu serta lebih baik untuk menjadi harapan” (Qs Al-Kahfi: 46). 
Dari arti ayat di atas dapat dipahami bahwasannya harta dan anak merupakan suatu perhiasan didalam dunia ini, dan juga mempunyai keturunan adalah suatu kebanggaan atau kebahagian tersendiri yang dirasakan pasangan suami-isteri, namun pada kenyataannya ada beberapa pasangan suami istri yang belum dikaruniai keturunan. Namun di dalam kehidupan nyata tidak semua pasangan suami istri dikarunia langsung keturunan tidak sedikit masalah atau konflik yang terjadi pada pasangan suami istri yang menimbulkan berbagai pertanyaan, ada yang mengungkapkannya secara langsung, ada yang hanya dipendam, atau sudah mengungkapkan akan tetapi respon pasangannya tidak memberikan jawaban atas pertanyaannya. Menjalani sebuah pernikahan bisa dikatakan bagi setiap pasangan tidak bisa memastikan konflik apa saja yang mereka hadapi bersama, banyak sekali persoalan yang muncul. Dari masalah ekonomi, masalah karir, pangasuh keturunan, masalah pergaulan, ketidakpuasan dalam hubungan seksual, perbedaan watak, perselingkuhan dan masih banyak lagi masalah-masalah yang lain, karena masalah yang terjadi pada pasangan suami istri sangat banyak sekali.

Dalam sebuah kisah Nabi yang sudah lanjut usia akan tetapi belum juga diberi anak oleh Allah SWT. Yaitu Nabi Zakariya As. Rambutnya telah memutih sedangkan istri beliau dikatakan orang mandul, tetapi beliau tidak putus asa memohon diri pada Allah SWT. Agar diberi anak yang sholeh yang bakal menggantikan perjuangan beliau menyuruh manusia menyembah Allah SWT. Lama kelamaan do'a Nabi Zakariya As. dikabulkan juga oleh Allah swt. Maka pada suatu saat datanglah Malaikat Jibral kepada Nabi Jibril kepada Nabi Zakaria yang pada waktu itu berada di Mihrob tempat ibadah. Malaikat Jibril memanggil-manggil dan member kabar gembira, bahwa Allah akan member kepada-Nya seorang anak laki-laki bernama Yahya yang akan menjadi Nabi dan Rasul pula (Makhsum).

Perkawinan tanpa kehadiran anak seringkali menimbulkan permasalahan atau problem tersendiri diantara suami istri, banyak pasangan suami istri yang yang sulit mendapat keturunan.Allah SW'T berfirman yang artinya: "Milik Allah-lah kerajaan langit dan bumi, Dia menciptakan apa yang Dia kehendaki. Dia memberikan anak-anak perempuan kepada siapa yang Dia kehendaki, dan memberikan anak-anak lelaki kepada siapa yang Dia kehendaki, atau Dia menganugerahkan kedua jenis laki-laki dan perempuan (kepada siapa) yang dikehendaki-Nya, dan Dia menjadikan mandul siapa yang Dia kehendaki. Sesungguhnya Dia Maha mengetahui lagi Maha Kuasa” (QS Asy-Syura: 49-50).

Memang tidak bisa dipungkiri di dalam kehidupan pasangan suami-istri permasalahan tidak memiliki anak bukanlah suatu hal yang mesti dihindari atau tidak ada sama sekali. Permasalahan memang sudah menjadi ketetapan dalam kehidupan manusia. Namun sejauh mana kemampuan suami-istri menghadapi permasalahannya itu, karena seperti yang dijelaskan ayat 
diatas bahwasannya sesungguhnya Allah lah yeng maha mengetahui lagi maha kuasa atas segalanya. Di dalam kehidupan pasangan suami istri yang yang belum memiliki anak di Kecamatan Kikim Timur, Kabupaten Lahat, Provinsi Sumatera Selatan, masalah ini sangat mengganggu dalam kehidupannya.Karena banyak sekali faktor yang mempengaruhinya, seperti dari keluarganya, lingkungannya maupun dari pasangan suami istri itu sendiri, maka dari itu peneliti ingin mengetahui lebih jauh masalah pasangan suami istri yang belum memiliki anak ini.

Maka dari itu berdasarkan survey awal yang penulis lakukan terhadap beberapa pasangan suami istri yang ada di Kecamatan Kikim Timur, Kabupaten Lahat, Provinsi Sumatera Selatan. Menurut pasangan suami istri YL dan HR tersebut awal menikah mereka masih merasakan suatu kebahagian dan ketenangan diantara mereka berdua, akan tetapi dengan berjalannya waktu, pasangan suami istri ini mulai bertanya-tanya kenapa belum mempunyai anak, kemudian temanteman sudah mempunyai anak semua, belum lagi adanya pertanyaan yang timbul dari orang tua yang menanyakan kapan bisa menimang cucu. Karena suaminya merupakan anak pertama, jadi kehadiran seorang cucu sangat ditunggu-tunggu dari pasangan YL dan HR ini, dari sinilah mereka mulai merasakan kegelisaan dan mereka mulai mencari info seputaran agar bisa hamil. Kemudian ada salah satu kelurganya menyarankan untuk berobat di pengobatan tradisional yang ada di desa lain, karena menurut keluarganya tersebut sudah banyak yang berhasil berobat di sana, dan mereka sudah pernah melakukan pengobatan medis akan tetapi tidak membuahkan hasil.

Selanjutnya keluarga dari pasangan suami istri RD dan PE awal pernikahan mereka juga masih merasakan kebahagian dan ketentraman juga dalam kehidupan mereka, dengan berjalannya waktu mereka merasakan kegelisaan khususnya istri karena belum hamil, akan tetapi suaminya tidak terlalu gelisa, kemudian pasangan ini mulai melakukan usaha-usaha agar hamil, akan tetapi belum juga membuahkan hasil. Berdasarkan penjelasan di atas, maka peneliti bertujuan untuk mengungkapkan bagaimana dinamika psikologis pasangan suami istri yang belum memiliki anak di Kecamatan Kikim Timur, Kabupaten Lahat, Provinsi Sumatera Selatan.

\section{METODE}

Penelitian ini menggunakan metode kualitatif dengan pendekatan studi kasus. Dengan demikian penelitian kualitatif dapat diartikan sebagai metode penelitian yang berlandaskan pada filsafat postpositivisme, digunakan untuk meneliti pada kondisi obyek yang alamiah, (sebagai lawannya adalah eksprimen) dimana peneliti sebagai instrumen kunci, teknik pengumpulan data dilakukan secara triangulasi (gabungan), analisis data bersifat data induktif atau kualitataif, dan hasil penelitian kualitatif lebih menekankan makna dari pada generalisasi (Sugiyono, 2013). 
Studi kasus adalah suatu proses pengumpulan data dan informasi secara mendalam, mendetail, intensif, holistik, dan sistematik tentang seseorang (Yusuf, 2014). Dalam pendekatan studi kasus, biasanya seorang peneliti akan meneliti satu individu atau unit sosial tertentu secara lebih mendalam. Dengan begitu, peneliti berusaha untuk menemukan semua variabel penting yang terikat dengan diri subjek yang diteliti. Selain itu, peneliti juga meneliti bagaimana perkembangan diri subjek, penyebab terjadinya hal tersebut, perilaku keseharian subjek, dan alasan perilaku itu dilakukan, serta bagaimana perilaku berubah dan penyebab terjadi perubahan perilaku tersebut (Idrus, 2009).

Adapun penggunaan pendekatan ini untuk memfokuskan dinamika psikologis pasangan suami istri yang belum memiliki keturunan. Hal inilah yang menjadi alasan untuk mengambil metode kualitatif dengan pendekatan studi kasus dalam memberikan gambaran pada penelitian ini. Teknik pemilihan informan menggunakan tenik purposive sampling adalah teknik pengambilan sampel sumber data dengan pertimbangan tertentu. Pertimbangan tertentu ini, misalnya orang tersebut yang dianggap paling tahu tentang apa yang kita harapkan, atau mungkin dia sebagai penguasa sehingga akan memudahkan peneliti menjelajahi obyek/situasi sosial yang diteliti (Sugiyono, 2009).

Untuk menetapkan informan, peneliti menggunakan kriteria berikut; 1) Pasangan suami istri yang belum memiliki keturunan, 2) Pasangan suami istri yang tinggal di Kecamatan Kikim Timur, Kabupaten Lahat, Provinsi Sumatera Selatan, 3) Bersedia menjadi responden dalam penelitian ini, 4) Usia pernikahan 4 tahun ke atas. Sumber data yang digunakan adalah sumberdata primer yaitu pasangan yang belum menikah, serta sumberdata sekunder yaitu keluarga drai pasnagan, serta studi dokumentasi. Teknik pengumpulan data menggunakan teknik wawancara, observasi dan studi dokumentasi, serta menggunakan trianggulasi sumber dan waktu untuk menguji keabsahan data, seterusnya untuk menganalisis data hasil penelitian mengunakan model Milers dan Hubermen, yang terdiri atas reduksi data, penyajian data dan pengambilan kesimpulan sementara (Sugiyono, 2009).

\section{HASIL DAN DISKUSI}

Berdasarkan penelitian ini dinamika psikologis yang dimaksud adalah Dinamika Psikologis Suami Istri yang Belum Memiliki Anak, yang mana dalam penelitian ini dinamika psikologis terdiri dari beberapa aspek, sebagai berikut: 


\section{Aspek Emosi}

Keterangan dari keenam pasangan suami istri yang berkaitan dengan apek emosi adalah sebagai berikut:

Pasangan Masrin dan Asnani, ditahun ketiga mereka berumah tangga mulai merasa cemas, karena belum mendapatkan anak, dengan berjalannya waktu ada suatu ketika mereka merasa terpuruk sekali, terutama ibu Asnani, karena pada saat itu pasangan ini akan diberi anak oleh keluarganya, akan tetapi pada saat keluarganya sudah melahirkan keluarganya tidak jadi memberikan anaknya dengan berbagai alasan, pasangan Masrin dan Asnani merasa sangat kecewa, dan ibu asnani jatuh sakit karena memikirkan hal tersebut, kejadian itu membuat pasangan ini sudah tidak terlalu perduli dengan anak-anak, pada saat ini pasangan suami istri ini sudah merasa pasrah, dan hanya fokus dengan bekal di akhirat nanti.

Pasangan Masrin dan Asnani

Sekitar taun ke tige behuma tangge kami mulai mehase cemas ngape sangkan belum ade anak ni padahal lah tige taun nikeah, taun ke empat sampai taun ke lime tambah cemas b pehasean, mane keluarge, tetangge lah nanye-nanye tu lab ngape sangkan belum hamil-bamil tu terutame endung sandi makwe tu, karne makwe ni anak gi subang inilah, jadi cucung sandi keluarge makwe tu dide bie yang kandung selain ngarapkah sandi makwe nil ah, laju tambah pening b palak uli jeme betanye tu lab $t$, nah sekitar taun kesepulah ape dide taun ke sebelas tu yang mehase keciwe nian gara-gara keluarge yang nak ngenjuk.kah anak nga kami anye dide jadi, padabal die tu lab bejanji nian, uy kan nay ase di permainkah nian, ase di ijak-ijak. kah jeme b kami ni, laju ade sekitar sebulan due bulan semang ngeluae buma, terutame makwe kaba ni yang merase tetekan nian, sekitar semingguan dide makan, laju tedemam-demam, pokonye lah ase kah gile uli kejadian itu, ame bakwe ni dide pule sampai tedemamdemak, dimak, pehasean tu, kecine pule, sekitar due puluban kami nikah, kami lah mulai dide rigat lagi uli belum be anak ni, sampai mak ini abi lah pasrab b nga keadaan luk ini mungkin memang lah ketentuan sandi Allah dide be anak.

Sekitar tahun ketiga berumah tangga mulai merasa cemas, karena sudah tiga tahun menikah masih belum memiliki anak juga. Tahun keempat dan kelima bertambah cemas, ditambah mendengar pertanyaan dari keluarga maupun tetangga yang menanyakan kapan hamil, terutama ibu dari istri, karena istri merupakan anak tunggal, oleh karena itu seorang cucu sangat dinantinanti, mendengar berbagai pertanyaan tersebut membuat kepala bertambah pusing, yang membuat kami suka bedebat karena ibu yang selalu menanyakan masalah anak, saya suka marah dengan ibu kalau bertanya masalah anak terus, karena membuat kepalah pusing, nafsu makan saya berkurang, menurut suami itu hal yang wajar kalau ibu selalu bertanya. Sekitar tahun kesepuluh atau kesebelas kami merasa kecewa sekali karena keluarga yang inging memberi kami seorang anak membatalkan janjinya itu, kami merasa dipermainkan, terasa dihina, dari kejadian itu lebih kurang satu bulan istri tidak keluar rumah, sekitar satu minggu tidak makan, sampai-sampai sakit, dengan kejadian tersebut membuat sertekan sekali, kemudian dari kejadian tersebut ibu mulai berkurang menanyakan masalah anak begitupun dengan tetangga, lebih kurang dua puluh tahun 
kami menikah, kami sudah mulai pasrah dengan kondisi seperti ini, sampai sekarang kami hanya pasrah memang sudah menjadi ketetapan dari Allah untuk tidak memiliki anak.

Pernyataan di atas diperkuat oleh ibu Nismiah tetangga pasangan Masrin dan Asnani:

Seingat aku ade nian waktu itu Asnani nga Masrin tu jarang ngeluae buma terutame Asnani tu, uli gara-gara nak ngambik anak sanaknye anye dide sanaknye ngenjukkahnye tu, asnani tu yang tedemamdemam kapo uli mikiri titu

Seingat saya dulu Asnani dengan Marsrin jarang keluar rumah, terutama Asnani, karena keluarga dari mereka tidak jadi memberikan anak dengan mereka padahal sebelumnya sudah dijanjikan, sampai-sampai asnani jatuh sakit, karena memikirkan hal tersebut.

Kemudian adapun yang diungkapkan oleh pasangan Sukarman dan Yuniarti

Mamang nga bibi mulain tehase gelisa tu sekitar tau ke due ke tigeanlah, pokoknye mulai betanye-tanye ngape lh sangkan belum be anak-anak ni, tabun ke lime tu tambah dimak gale pebasean uli nginak jeme yang setannan b nikah dulu, kence-kance akrab dulu lab hamil gale ade yang lab hamil anak kedue, sedangkah kami belum nian same sekali, sekitar taun ke tujuban tebak an sandi bada bebubat pacak diumungkah dukun. Bibi ni lah hamil due bulan, anye dide bie tande-tande luk jeme hamil tu, temuntah kapo dide, kami umungkah nga jeme bada behubat tu, ujinye belum die kah tehase, dem kami percaye b, pokoknye lab besak nian harapan tu, lah sekitar empat, lime bulannye masib belum bie tande-tande jeme hamil, udim tu diumungkah lagi nga bada bebubat tu anye segale ade lah alasannye. Nengae bemacammacam sandi dukun tu laju buat emosi bibi ni naik, laju belage umungan disitu, lah nangis maraung kapo mane bibi tu lah ngarap nian, itulah uli nak hamil benae tu tape umungan jeme tu percaye b, dide pule tepikir nak ngecek pakai alat peranti nak. ngeruani hamil ape dide tu, udim kejadian itu laju dide pernah behubat dusun lagi, sekitar taun kesembilanan kami program ke dokter anye dide pule behasil, kadangan tu galak merenungi tape lah kesalan sangkan dide hamil-hamil ni, pehasean dide pule banyak gawehan yang aneh masih gadis nga bujang dulu, pernah dulu sekitar sebelas taun ape dide duebelas taun nikah bibi ngajung mamang bebini lagi siape tau pacak hamil kan ame nga tine lain, malahan mamang purik die, ujinye ame aku nak nikeab lagi lemaklah sandi dulu ujimye, nah kalu lah mak ini lah dide pule tehase ige nak be anak t, soalnye lah enam belas taun nikah ni laju belum ade anak, anye sampai make ini kami masih ade keyakinan suatu saat kele ame Allah nak nakdirkah ade anak masib kah di enjuk. nye.

Paman dengan bibi mulai merasakan kegelisaan karena belum mempunyai anak sekitar tahun kedua dan ketiga, mulai bertanya-tanya kenapa belum ada anak, tahun ke lima tambah merasa kegelisahan dan cemas, karena orang yang menikah ditahun yang sama dengan kami, teman-teman dekat dulu sudah hamil semua, bahkan sudah ada yang hamil anak kedua, sedangkan kami belum sama sekali. Sekitar tahun ketujuh, bibik pernah diprediksi oleh orang yang tempat bibi dengan paman berobat bisa dikatakan dukun sudah hamil dua bulan, akan tetapi tidak merasakan tanda-tanda orang hamil, dan kata orang tempat berobat tersebut memang belum terasa kalau masih dua bulan, setelah empat bulan atau lima bulan, kami pergi lagi ke rumah orang tersebut untuk menanyakan kenapa sampai sekarang belum juga ada tanda-tanda kehamilan, dan orang tersebut menjawab dengan berbagai alasan, emosi bibi langsung naik, dan saat itu bibi langsung marah dengan orang tersebut, bahkan pada saat itu bibi sudah tidak ada rasa malu lagi menangis dengan suara keras, karena paman dengan bibi sudah memiliki harapan yang 
besar. Karena kami sangat menginginkan seorang anak semua omongan orang tersebut dipercayai semua, setelah kejadian tersebut kami tidak pernah lagi berobat dusun atau tradisional. Sekitar tahun kesembilan kami melakukan program ke dokter, tetapi belum juga berhasil, terkadang suka merenung, sambil berpikir apa kesalah yang telah dibuat dimasa lalu, akan tetapi tidak ada kelakuan yang aneh-aneh disaat masih bujang dan gadis dulu. Sekitar tahun ke sebelas atau dua belas bibi menawarkan agar paman menikah lagi, karena dengan harapan siapa tau bisa ada keturunan, malahan paman marah kataanya kalau saya mau menikah lagi sudah dari dulu, kalau sekarang kami masih punya keyakiana kalau ditakdirkan oleh Allah untuk ada anak pasti suatu saat akan ada anak juga.

Selanjutnya adapun yang diungkapkan oleh pasangan Hendri dan Yela

Sekitar taun ketige kakak nga ayuk ni mulai tehase gelisa, cemas, betanye-tanye ngape lah sangkan belum bamil ni, kadangan tu galak. nangis subang uli dide bie anak ni, nak program ke dokter duit ni belum $t$ la ade, duit untuk makan b untung ade, ame bebubat dusun ni lab neman, yang galak buat ayuk sakit ati ni umungan sandi keluarge kakak ni yang galak ngumungkah kalu yang mandul tu ayuk ni, dalam ati ayuk bukan galak. luluk ini karne ayuk ni lah pernab belaki sebelumnye anye belum bie anak, sekitar setaun lah mangke ayuk sahak, dide nak dibahas lagi, masa lalu titu, sekitar di taun ke enam ape dide tujub mentue ayuk ni tandang kehuma kami, masib nia tehingat ayuk tige malam die tandang tu masih biase b, nah malam keempat tu die ngumung nga ayuk kakak dang dide bie di buma, ujinye minta lah sahak $b$ nga Hendri tu, uy nengae umungan itu jantung ayuk ni langsung degak degup, udim tu sambil nangis ayuk nangis ngumung nga mentue ayuk tu ame kakak Hendri nak sabak aku lah rela pule mak, tapi Alhamdulillah kakak ni sayang nga ayuk dide die nengae $i$ umungan keluargenye, pokoknye kalu dulu tu dang belanju ke bada kakak di Sekayu tu ase dide kah balik uli dimak gale umungan sandi keluarge di Sekayu tu, itu lah pule yang buat ayuk semang neman ige belanju ke Sekayu, lagian pule dik bie duit nak belanju tulah. Kalu kakak ni die dide pule desak ige die, ade pule kakak ni ase dimak gale keadaan luluk ni, anye kah luk mane.

Sekitar tahun ketiga kakak dengan ayuk menikah mulai merasa gelisa, cemas, bertanya-tanya kenapa belum hamil-hamil, terkadang suka menangis sendiri karena belum ada keturunan, ada niat untuk melakukan program ke dokter tapi biaya belum ada, makan untuk sehari-hari untung cukup, hanya berobat tradisional yang bisa di lakukan, yang sering membuat ayuk sedih dan sakit hati omongan dari keluaga suami yang sering berbicara kalau yang mandul itu ayuk, karena ayuk dulu sudah menikah selama satu tahun sebelum dengan kakak, dan kemudian bercerai yang disebabkan beberapa faktor, tidak usah diingat lagi masa lalu itu. Sekitar ditahun keenam atau ketujuh, sampai sekarang masih ayuk ingat mertua ayuk nginap di rumah kami, malam ketiga masih terasa biasa saja, dimalam keempat mertua ayuk ngobrol dengan ayuk, waktu itu kakak lagi di luar, kata mertua ayuk kamu harus mintak cerai dengan hendri, dengar omongan mertua tersebut jantung ayuk langsung berdenyut kencang, dengan menangis ayuk menjawab kalau kak Hendri ingin menceraikan saya rela, tapi Alhamdulillah kakak ni sayang dengan ayuk, omongan dari keluarganya tidak terlalu di dengarkannya. Oleh sebab itu yang membuat saya malas mudik ke 
Sekayu, selain itu karena tidak ada uang, kalau kakak ni dek rasa cemas tu pasti ada, tapi bagaimana dek memang begini lah kenyataannya.

Berikutnya berdasarkan ungkapan pasangan Marwadi dan Sri

Sekitar setahun nikah lah ade tekanan sandi endung suami yang selalu nanyekah ngape belum hamil, anye kami masib mehase aman b, di taun ke tige kami mulai mehase cemas uli belum ade anak, pokoknye lah mehase khawatir nian di tabun ke empat ayuk nga kakak ni ngikut program tapi belum behasil. Sekitar taun ke enam ngikut program lagi Alhamdulillah itu behasil, tapi sayangnye dek ayuk keguguran, padabal lab empat bulanan di situ ayuk tehase stress nian, tige abi ape dide empat abian dide ngeluae kamar, makan b diambikah kakak, itu b kadang galak, kadang dindak, nangis t lah gawehan, pokonye sgegale dimak, karne lah senang nian, mangke keguguran, sampai mak ini tibe-tibe tehingat laju nangis.

Sekitar satu tahun menikah itu sudah ada tekanan dari ibu dari suami yang selalu menanyakan kenapa belum hamil, akan tetapi kami belum merasakan kegelisahan, ditahun ketiga kami mulai merasa cemas dan gelisa karena belum ada anak, ditahun ke empat kakak dengan ayuk mengikuti program, akan tetapi belum berhasil. Tahun keenam kami mencoba lagi, dengan berbeda dokter dan Alhamdulillah berhasil, tetapi sayangnya ayuk keguguran padahal sudah empat bulan, pada saat itu ayuk merasa sangat stress, sekitar tiga hari ayuk hanya di kamar, makan diambilkan oleh kakak, itupun terkadang tidak dimakan, di situlah terasa sangat sedih sekali, makan kurang, sampai sekarang masih suka terbayang dan akhirnya menangis.

Selanjutnya adapun yang diungkapkan oleh Riswandi dan Suhaini

Awal nikah dulu tu dek aynk lah mehase cemas dide bie anak, karne aynk ni nikah dulu lab umur 34 taun, sebelumnye lah ayuk jelaskah gale nga kakak dan kakak galak nerime ayuk, luk itu pule nga keluargenye, taun kedue nga ke tige ayuk nga kakak tambah tambah cemas terutame ayuk, di tambah lagi sindiran sandi tetangge yang galak. nyindir jangan nikah tu umur lah tue ige, kele dide behanak, kadang tu ayuk tu galak nyesali dibi diwik dek, karne nikeab umur lab tue ni, anye kah luk mane dek bukan galak ayuk nikah umur 34 taun tu, makmane ame belum ade jodoh, ayuk. kaba ni dek mudah nae tesinggung nengae jeme ngumung luk itu, kadang tu galak dide makan uli tebingat umungan jeme tu udim tu galak ngelamun, kalu kakak ni dek dide peduli jme nak ngumung luk mne.

Awal menikah dulu dek sudah ada perasaan cemas tidak memiliki anak karena saya menikah sudah berumur 34 tahun, sebelum nya sudah dijelaskan dengan kakak dan kakak mau menerima ayuk apa adanya, begitupun dengan keluarganya, tahun kedua dan ketiga ayuk dan kakak tambah cemas terutama ayuk, di tambah lagi dengan sindiran-sindaran dari tetangga yang selalu ngomong jangan menikah terlalu tua, nanti susah memiliki anak, terkadang ayuk suka menyesali diri ayuk sendiri karena menikah terlalu tua, karena mendengar sindiran dari tetangga ayuk kamu ni suka mogok makan, melamun karena dek ayuk ni mudah sekali tersinggung dan omongan orang langsung masuk ke pikiran, kalau kakak tidak perduli apa yang di omongi oleh tetangga dek.

Selanjutnya pasangan Ridhi dan Pely

Taun pertame nikah dulu t kami belum merase cemas, soalnye empai nikah kan, dang bahagiabahagianye, mane di lingkungan pesantren pule kan otomatis banyak santri-santri tu, taun kedue akbir 
tu lah mulai agak cemas t kan dek, nah ditaun ke empat tu terase putus asa nian aynk, soalnye ayuk ni operasi kista, mane di dalam pikiran ayuk tu dem lah dide nian bie harapan nak hamil t ame lah udim operasi kista tu. Ade cak seminggu ayuk dide ngajar, due abi tu melamun tulah gawehan sambil nangis, makan kurang, malam ketige tu kakak bangunkah ayuk ngajak shalat tahajud, ayuk bedoa sambil nangis sejadi-jadinye, udim itulah ayuk merase tenang juge dan ayuk masib bersyukur mentue ayuk nunggui selame sebulan, udim tu kakak ni yang selalu ngenjuk semangat, pokoknye lingkungan ni selalu ngenjuk semangat tula terutame istri pimpinan pondok ni, berkat nesehat-nasehat yang ade akbirnye laju ad eke inginan nak bebubat lagi, sampai saat ini masib behubat tapi nyube bebubat dusun.

Tahun pertama menikah dulu kami belum merasa cemas, soalnya baru menikah dan lagi bahagia-bahagianya, ditambah di lingkungan pesantren yang otomatis banyak santri-santrinya, akhir tahun kedua mulai merasa agak cemas, di tahun ke empat terasa putus asa, karena operasi kista, ditambah lagi dalam pikiran ayuk kalau sudah melakukan operasi kista, tidak ada lagi harapan untuk hamil, sekitar satu minggu ayuk tidak mengajar, sekitar dua hari ayuk selalu menangis dan melamun, makan kurang, malam ketiga kakak membangunkan ayuk untuk shalat tahajud, sepanjang shalat ayuk menangis dan disaat berdoa ayuk menangis sejadi-jadinya, setelah shalat tahajud ayuk merasa lebih tenang, dan ayuk bersyukur karena memiliki mertua yang perhatian dan rela nginap selama satu bulan di rumah, kakak yang selalu memberikan semangat, ditambah lingkungan yang selalu memberikan semangat juga terutama istri dari pimpinan pondok, berkat nasehat-nasehat yang ada akhirnya ayuk mau berobat lagi.

Selama kegiatan proses wawancara dengan pasangan suami istri yang belum memiliki anak terlihat dari beberapa mukanya pasangan suami istri yang merasakan kesedihan yang sangat mendalam, bahkan mereka ada yang meneteskan air mata pada saat wawancara, kemudian hasil wawancara di atas dapat diketahui bahwa aspek emosi yang dialami oleh pasangan suami istri yang belum memiliki anak mengalami perubahan emosi, tiga tahun menikah mereka mulai merasa cemas dan khawatir karena belum memiliki anak, dengan berjalannya waktu ada beberapa pasangan yang sudah merasa pasrah, karena sudah 39 tahun menikah akan tetapi belum juga memiliki anak, ada juga yang masih memiliki keyakinan untuk ada anak. 


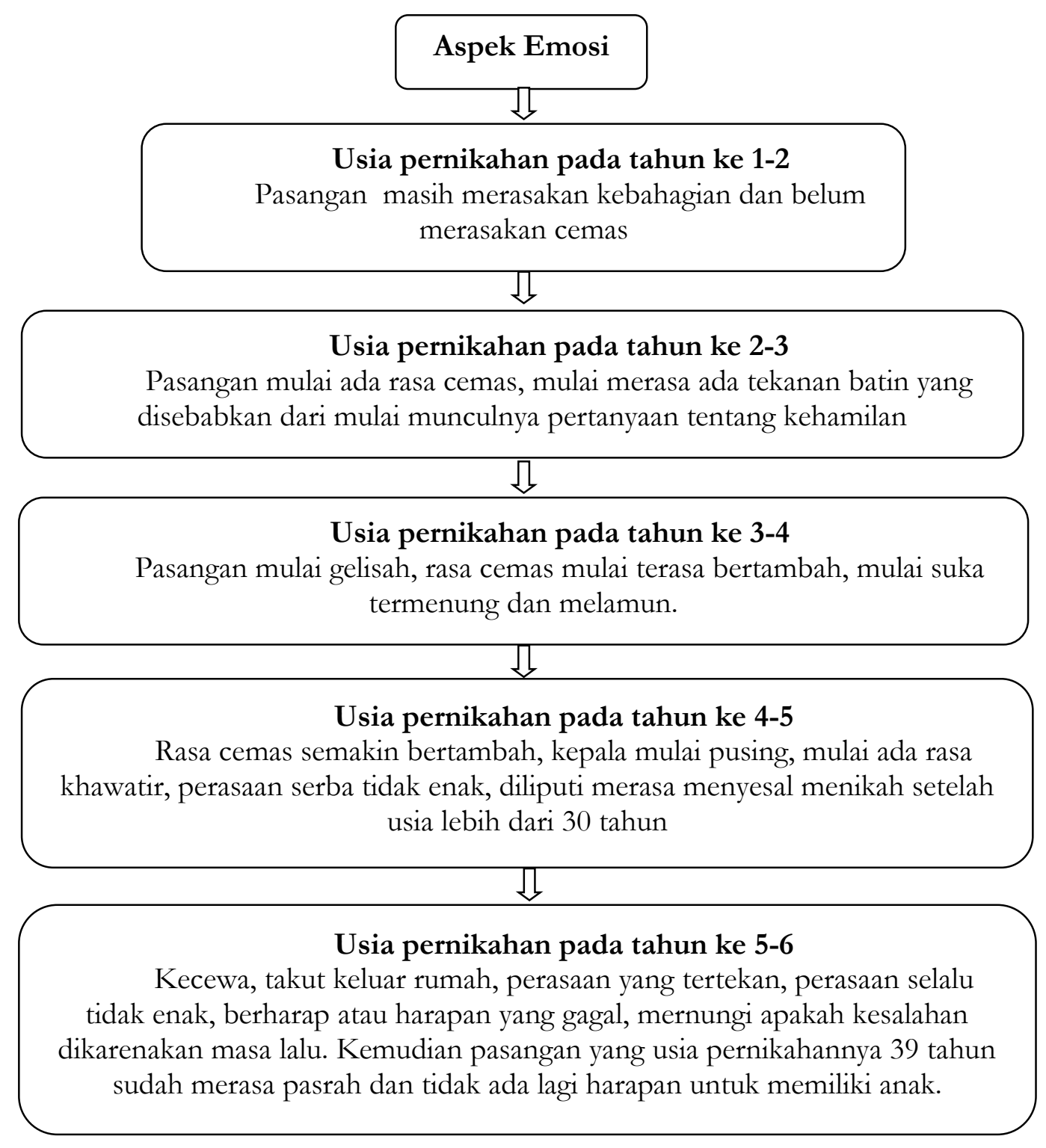

Bagan 1. Aspek emosi pasangan suami istri yang belum memiliki anak

\section{Aspek Penyesuaian Diri}

Adapun hal yang berkaitan dengan aspek penyesuaian diri sebagai berikut: Pasangan Masrin dan Asnani dalam menyesuaikan diri dengan lingkungan keluarga, tetangga, ataupun teman dekat mereka tidak mengalami kesulitan, dan mereka sangat terbuka atau menyayangi anak kecil dengan berjalannya waktu ada kejadian yang membuat mereka sangat kecewa, mereka tidak terlalu terbuka dengan anak kecil, dan sekarang pasangan ini lebih fokus untuk ibadah.

kalu taun pertame bakwe nga makwe nikah dulu, nak nyesuaikah dibi nga lingkungan keluarge, tetangge kapo tu dide terlalu sulit, soalnye bakwe nga makwe ni sedusun jadi lab tebiase, dide merase sungkan, nah kalu masalah anak ni taun kedue lah mulai keluarge nanyei kebile mangke hamil, terutame jeme tue sandi makwe ni yang betanye tulah, soalnye makwe anak tunggal, dengan bejalannye waktu kalu dengae kance ape dide tetangge yang lah hamil, di dalam ati bedoa semoga aku jerang lagi hamil pule, udim tu sebelum 
kejadian ade keluarge yang nak ngenjuk kami anak anye dide jadi, kami masih sangat agam nga anakanak kecil, luluk keponakan, anake tetangge, akan tetapi setelah kejadian itu kami lah bersikap biasae bae nginak anak kecik, paling budak kecike tetentu yang masih agam tu ame, mak ini kami lah fokus untuk ibadah.

Adapun maksud penjelasan dari pasangan Masrin dan Asnani ini, pada tahun pertama menikah dulu, untuk berinteraksi atau menyesuaikan diri dengan lingkungan keluarga dan tetangga tidak terlalu susah, karena menikah satu dusun, jadi sedikit banyaknya sudah paham satu sama lainnya. Tahun kedua menikah sudah mulai pertanyaan-pertanyaan mengenai anak, seperti orang tua dari istri, karena istri saya merupakan anak tunggal, jadi seorang cucu itu sangat dinantinanti, dengan berjalannya waktu teman-teman sudah memiliki anak semua dan tetangga ada yang hamil, hanya bisa berdoa semoga suatu saat bisa hamil juga, sebelum kejadian ada keluarga yang ingin memberi kami anak tetapi tidak jadi, kami masih sangat menyayangi anak-anak kecil, seperti keponakan, anak tetangga, akan tetapi setelah kejadian itu kami sudah bersikap biasa saja melihat anak kecil, dan sekarang kami hanya fokus untuk ibadah.

\section{Pasangan Sukarman dan Yuniarti}

ame bibi nga mamang ni untuk nyesuaikah dibi di lingkungan jeme yang lah ade anak ni baik itu keluarge, kance, tetangge dide pule terlalu sukae nian, saolnye sandi pibak mamang nga bibi die ngerti gale nga keadaan mak ini. Lagi pule kami bedue ni ame nginak budak kecik tu agam nian lab ase anak. diwik. Paling ade lab beberape tetangge yang galak nyindir-nyindir ape ngumungkah masalah anak ni, bibi jawab b doakah saje.

Paman dan bibi untuk menyesuaikan diri di lingkungan orang yang sudah memiliki anak tidak terlalu sulit, karena dari pihak keluarga kami berdua sangat mengerti dengan kondisi kami sekarang, dan juga kami berdua sangat menyayangi keponakan-keponakan atau anak kecil dan mereka trasa anak sendiri. Walaupun ada beberapa tetangga yang menyindir atau berbicara masalah anak, kami jawab doakan saja.

Hal serupa yang diungkapkan oleh pasangan Hendri dan Yela

kakak nga ayuk ame nga tetangge ape nga keluarge sebelah ayuk dide pule sukae nyesuaikah dibi tu. Nab ame nga keluarge sebelah kakak ni yang sukae karne caknye luluke dide senang nga budak kecik, Udim tu kalu nginak budak kecik, tu ase anake divik, luluk anak cik an kami tu selalu kami sise kah duit untuk. belikeah hadiah ulang tabunnye.

Kalau kakak dengan ayuk tidak terlalu sulit untuk menyesuaikan diri dengan tetangga, keluarga dari ayuk, kalau keluarga dari kakak sangat susah sekali, karena sepertinya mereka tidak terlalu senang dengan ayuk, kalau melihat anak kecil terasa anak sendiri, seperti anak bibi selalu kami sisa uang untuk membelikan ia hadiah setiap ulang tahunnya. 
Pernyataan di atas diperkuat oleh Leni sepupu dari Yela:

Kalau Heri dengan Yela, dalam kesehariannya mereka sangat terbuka dengan anak kecil, babkan setiap anak saya ulang tabun mereka selalu memberikan hadiah.

Hal serupa yang diungkapkan oleh Marwadi dan Sri

kalu masalah keturunan ni endung kakak. ni yang galak. nanye kah masalab keturunan ni, ape lagi kalu dang galak. ngumpul-ngumpul nga keluarge yang lain pasti mertue aynk dulu sekali yang bahas tentang anak tu,kadangan tu galak. minder, ame keluarge sebelah ayuk. Alhamdulillah ngerti die.

Kalau masalah keturunan ini ibu dari suami yang sering menanyakan kapan hamil, apa lagi disaat berkumpul bersama keluarga yang lain, ibu dari suami yang pertama sekali membahas tentang anak, terkadang ada rasa minder disaat kumpul keluarga kalau keluarga dari istri Alhamdulillah mengerti.

Begitupun dengan pasangan Riswandi dan Suhaini

kalu dang ngumpul nga keluarge tu kadangan dindak benae ayuk nurutkabnye, tapi luk mane resiko ayuk masih sehuma nga jeme tue di dusun kalu make ini lah ninggal gale jeme tue kami tu, jadi ame jeme balik dang ade acara ape dang raye pastilah balik ke buma ni, kadang tu ayuk ade ase minder karne ading ayuk lab ade anaknye, tapi sebenarnye anak adding tu lab ase anak diwik walaupun bukan udim tu, keluarge ayuk ngerti nga keadaan ayuk dengan kakak mak ini. Ade lab beberape jeme yang galak ngumungkah, galak nyindir-ngindir masalah jangan nikah tu umur lah tue ige, kele dide beanak, paling ayuk senyum-senyum b, kalu dindak nengaei nye ayuk tinggalkah pegi.

Pada saat berkumpul dengan keluarga terkadang merasa malas, tpi tidak bisa dihindari karena kami tinggal serumah dengan orang tua di dusun, kalau sekarang sudah meninggal semua orang tua kami, jadi pada saat ada acara atau lebaran saudara pada pulang kerumah ini, terkadang ayuk ni ada rasa minder karena adek-adek sudah mempunyai anak, rasanya ingin diambil saja anak-anak adek tu seandainya dikasihkan, padahal keluarga mengerti dengan kondisi kami. Ada beberapa orang yang suka menyindir menikah itu jangan terlalu tua, takutnya susah untuk mendapatkan keturunan.

Kemudian pasangan Ridhi dan Pely

taun pertame ayuk nga kakak menikah belum banyak yang nanyekah masalah ketururnan, lagian pule seminggu udim nikah t kakak nga ayuk balik lagi ke pesantren lagi karena kami mengajar disana, sekitar taun-taun ke due tu kalu dang balike ke dusun ayuk dipagar alam ape ke dusun kakake di sp 5, paling ade keluarge nga tetangge yang galak nanye ngumung lab ngisi belum, kami jawab Allah lebih keruan waktu yang iluk untuk kami ade anak udim tu kami enjuk senyuman $b$.

Tahun pertama menikah belum banyak yang menanyakan masalah keturunan, karena satu minggu menikah kami kembali lagi ke pesantren yang ada di bungamas karena kami mengajar di sana, sekitar tahun kedua pada saat pulang ke Pagaralam atau ke sp 5, ada beberapa dan keluarga yang menanyakan sudah mengisi apa belum, kami hanya bisa ngomong Allah lebih tau kapan waktu yang terbaik utuk kami mendapatkan anak dan kami tersenyun.” 
Dari hasi wawancara dan observasi dapat diketahui bahwa pasangan yang belum memiliki anak di Kecamatan Kikim Timur, mereka dalam beradaptasi atau dalam menyesuaikan diri dengan lingkungan keluarga, tetangga, maupun masyarakat umum yang telah memiliki anak atau yang berbicara masalah anak, sebagian pasangan tidak mengalami kesulitan, akan tetapi ada yang merasa minder, dan ada juga yang merasa tidak nyaman dalam berinteraksi dengan pihak keluarga suami yang selalu menyalahkan.

Adapun bagan dari aspek penyesuaian diri pasangan suami istri yang belum memiliki anak bahwa yang mandul adalah pihak istri.

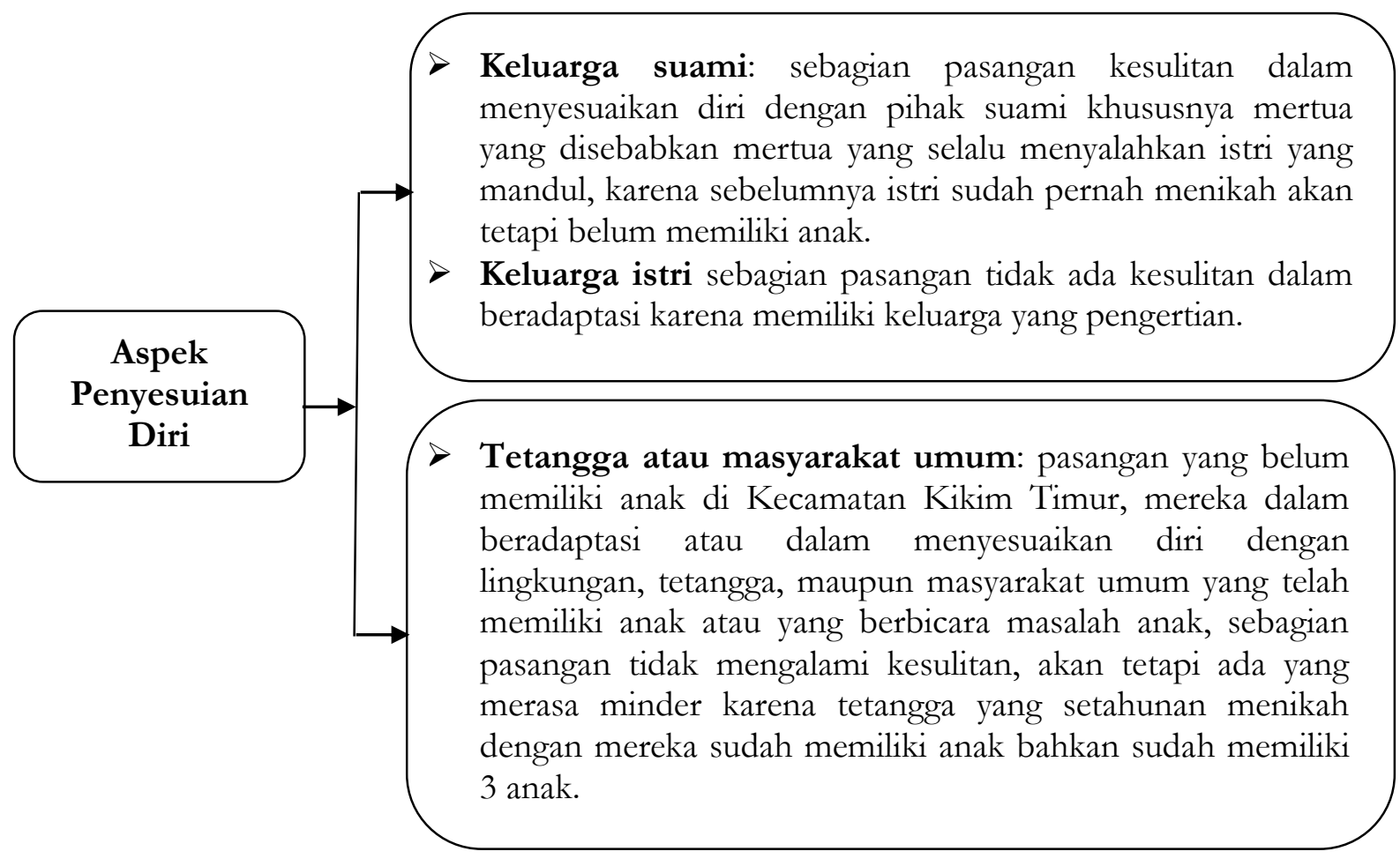

Bagan 2. Aspek penyesuaian diri pasangan suami istri yang belum memiliki anak

\section{Motivasi}

Pasangan yang belum memiliki anak di Kecamatan Kikim Timur, dilihat dari aspek motivasi ada sebagian dari mereka mendapatkan dukungan dan saran dari berbagai pihak, seperti keluarga, tetangga maupun masyarakan umum, dan sebagian dari mereka tidak ada lagi motivasi untuk memiliki anak, mereka hanya pasrah saja.

Pasangan Masrin dan Asnani

kalu masib awal nikah dulu keinginan nak ade anak tu masib besak nian, keluarge selalu ngenjuk semangat mangke tetap semangat, tpi endung sandi makwe ni yang selalu ngumungkah masalab anak udim tu selalu ngenjuk saran bebubat kemane-mane, terutame bebubat tradisional. Selain itu kami kalu dang shalat tu selalu bedoa mangke ade anak, ungtuk mengadopsi anak kami tu lah trauma pule, karne kejadian waktu itu. Pada saat itu Alhamdulillah keluarge yang lain ngenjuk dukungan terus mangke 
tetap besabar, jangan putus asa nga selalu bedoa. Kalu lah mak ini kami bedue ni lah saling nguatkah karne umur setue ini masih belum pule ade anak, lagian kami lah pasrah pule mak ini, lebih mikirkah untuk ibadah $b$.

Awal menikah dulu keinginan untuk memiliki anak masih sangat berharap, keluarga selalu memberikan dukungan untuk tetap semangat, ibu dari istri selalu memberi saran tempat-tempat berobat tradisional dan tempat medis, selain itu disaat kami shalat selalu berdoa agar di beri keturunan, dengan berjalannya waktu pada saat itu kami merasa kecewa sekali dan tidak ada lagi niat untuk mengadopsi anak, karena kejadian tersebut, tetap bersyukur keluarge yang lain masih meberikan dukungan agar selalu tetap bersabar, berdoa jangan putus asa.Kalau sekarang kami berdua saling menguatkah karena umur sudah tua masih belum memiliki anak.Sekarang lebih fokus untuk ibadah karena sudah tidak ada harapan untuk memiliki anak.

Pernyataan di atas diperkuat oleh Nismiah selaku tetangga dari Masrin dan Asnani:

Sepengetabuan saya sekarang ini keseharian dari pasangan ini Masrin dan Asnani lebih sering mengikuti kegiatan keagamaan, apalagi setelah mereka pulang dari ibadah haji. Mereka lebih giat.

Pasangan Sukarman dan Yuniarti

Alhamdulillah kalu keluarge mamang nga bibi ni selalu ngenjuk dukungan untuk tetap semangat, jangan putus asa, jangan mudab nyagu behubat kemane kina t nyarankah behubat kemane-mane, udim tu mamang ni pengertian die, dide die banyak tuntutan, lagian kalu mak ini ade anak tetangge ni yang hapat behusik udim t galak mikut kami kemane kina, Alhamdulilab pule endung bapangnye dide purik, tape sandi bayi galak di titipkah di bumah ni lah.

Alhamdulillah keluarga dari kami berdua slalu memberikan dukungan agar tetap semangat, jangan putus asa, jangan mudah bosan untuk selalu berobat, kemudian suami saya selalu pengertian dan tidak banyak tuntutan, kalau sekarang ada anak tetangga yang sering main ke rumah, dan Alhamdulillah juga orang tuanya tidak marah, memang dari bayi ia sering di titipkan dengan kami.

Kemudian Pasangan Hendri dan Yela

yang galak ngenjuk dukungan ape saran nga kami ni ade keluarge sandi ayuk ni, karne die dulu lame pule mangke ade anak sekitar lime taunan, nah jadi die tu selalu ngenjuk pengalaman, klu sandi jeme tue yang selalu ngnjuk semangat nga saran tu kisan di ayuk. ni, udim tu kami bedue nil ah saling nguatkah, ame niat nak ngambik anak, jeme tu ade kalu ade lukaknye.

Ada salah satu keluarga yang selalu memberikan dukungan atau saran dengan kami berdua, karena mereka dulu lima tahun baru ada anak nya, jadi mereka selalu memberikan pengalamannya. Kalau dari orang tua kami yang selalu memberikan dukungan dan saran itu dari keluarga istri, kemudian hanya kami berdua saling menguatkan, seandainya ada orang yang ingin memberikan anak kami bersedia, sayang nya untuk saat ini belum ada. 
Hal serupa yang disampaikan Pasangan Marwadi dan Sri

kalu kami bedue ni endung sebelah ayuk ni yang galak ngenjuk-ngenjuk nasehat, kalu endung sebelah kakak ni die tu lebih ke desak-desak tulah nanyekah kebile lagi mangke hamil, ame tetangge ni ade yang galak. ngenjuk saran kapo, udim tu ade pule yang nak ngumungkah b pacakan nye.

Yang sering memberikan motivasi atau nasehat maupun saran kepada kami berdua ibu dari istri, kalau ibu dari suami ia selalu menanyakan kapan hamil, kesannya lebih mendesak, kalau tetangga beberapa ada yang sering memberikan motivasi, sebagian ada juga yang sering menyindir.

Pasangan Riswandi dan Suhaini

sebelum jeme tue kami ninggal dulu tu die tulah yang galak ngenjuk dukungan mangke kami tu terus sabar nga kondisi kami mak. ini, kalu mak ini kami bedue ni lah saling nyemangati.

Sebelum orang tua kami meninggal ia lah yang sering memberikan dukungan agar kami terus bersabar dengan kondisi kami saat ini, kalau sekarang hanya kami berdua yang saling mendukung satu sama lain

Pasangan Ridhi dan Pely

yang selalu ngenjuk dukungan nga kami ni selain jeme tue ade bini sandi pimpinan pondok bada kami ngajar ni, die tu lah galah ngenjuk motivasi, semangat. Ape lagi pas ayuk udim operasi kista tu, pokoknye die tu lah yang paling neman ngenjuk dukungan. Udim tu kakak ni die ngerti nian nga keadaan ayuk mak ini.

Selain orang tua ada seorang isteri dari pimpinan pondok tempat kami berdua mengajar yang selalu memberikan dukungan semangat agar tetap selalu tegar, apa lagi pada saat ayuk habis operasi kista dulu, yang paling utama tu suami saya sangat mengerti kondisi ayuk sekarang.

Pernyataan di atas diperkuat oleh Wili tetangga Ridhi dan Pely:

dilihat dari kesehariannya pasangan ini sangat menginspirasi, karena mereka saling mengerti kondisi satu sama lain, terutama suaminya yang selalu memberikan semangat kepada isterinya pasca operasi kista.

Dapat diketahui motivasi dari pasangan yang belum memiliki anak di kecamatan Kikim Timur dari berbagai pihak seperti keluarga, tetangga, dan yang lainnya.

Adapun bagan dari aspek motivasi pasangan suami istri yang belum memiliki anak dapat dilihat pada bagan berikut: 


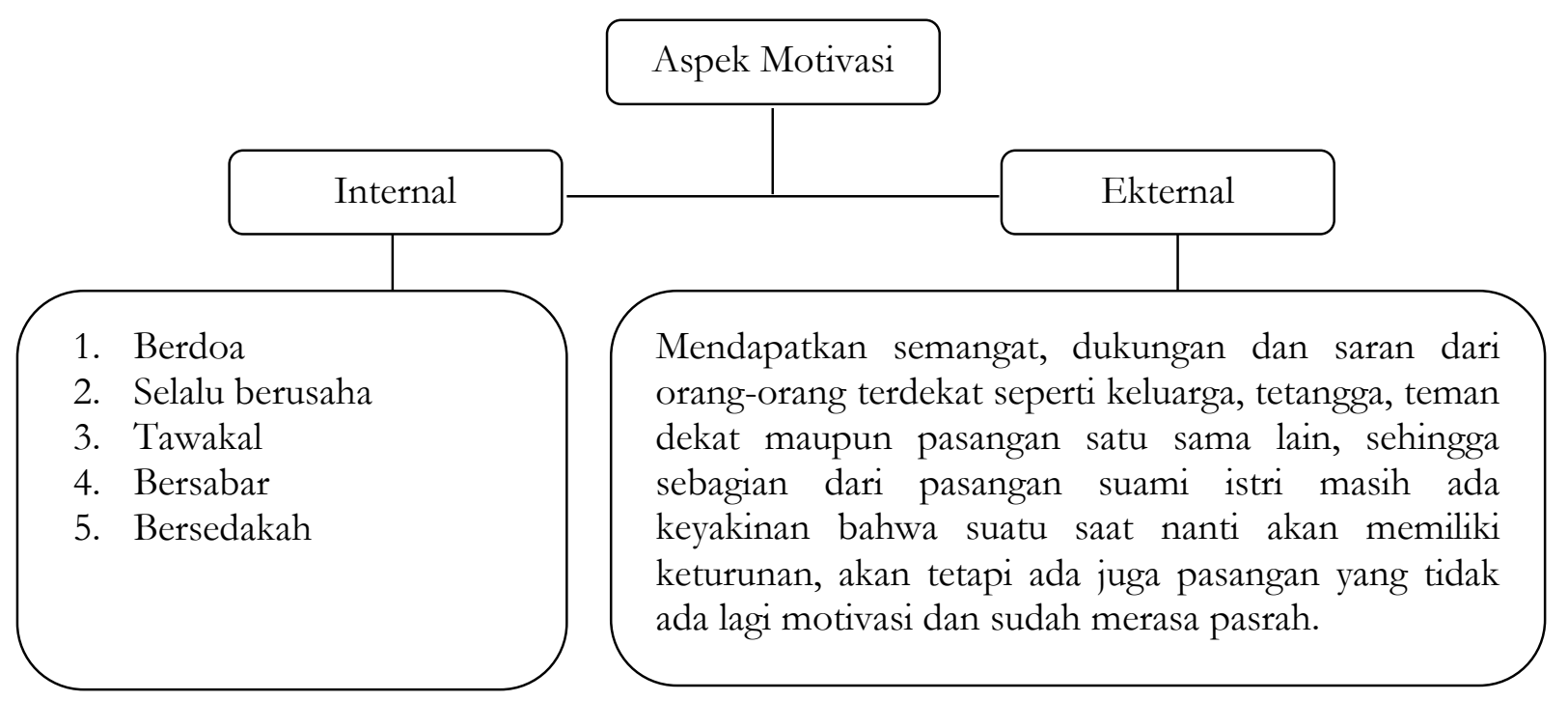

Bagan 3. Aspek motivasi pasangan suami istri yang belum memiliki anak

\section{Upaya yang Dilakukakan Pasangan Suami Isteri dalam Mengatasi Masalah Psikologis}

Berdasarkan hasil penelitian yang telah dilakukan terhadap pasangan suami istri yang belum memiliki anak, adapun upaya yang dilakukan dalam mengatasi masalah psikologis sebagai berikut:

Adapun yang diungkapkan oleh pasangan suami isteri Masrin dan Asnani

ay ame bakwe nga makwe ni kalu dulu masih mlakukan upaya berobat kemana-mana, deengan berjalannya waktu sudah pasrah, ame dang tepikir nga masalah keturunan ni biasenye nyakae kegiatan, luluk kami biasenye ame makwe galak nunggui warung, ame bakwo galak ke kebun biasenye, kalu mak. ini galak mgikuti kegiatan pengajian setiap hari rabu tu, udim tu semenjak kami udim naik haji taun 2017 tu lah yang dipikirkah mak ini lebih banyak mikir ke akbirat, behubung umur lah tue pule.

Kalau awal-awal menikah masih melakukan upaya berobat kemana-mana, dengan berjalannya waktu sudah pasrah, karena merasa sudah lansia, kemudian dulu disaat terpikir dengan masalah keturunan biasanya mencari kegiatan, kalau istri biasanya lebih sering ke warung, kalau suami biasanya ke kebun. Kalau sekarang lebih sering mengikuti kegiatan pengajian setiap hari rabu, kemudian semenjak sudah menunaikan ibadah haji pada tahun 2017 kami berdua lebih banyak memikirkan masalah akhirat, berhubung juga umur sudah tua.

Kemudian hal serupa yang diungkapkan juga oleh pasangan Sukarman dan Yuniarti

beberape taun nikah, banyak upayae yang digawekah mangke ade anak ni, bebubat dusun, bebubat ke dokter, ame mak ini Cuma ade harapan b, kemudian kalu kakak nga ayuk ni dek hobi midang, jadi kalu dang stress $t$ di batak midang t lab lagi, saye mak ini ade anak tetangge tu yang hapat ke buma ni, jadi galak pule mbataki die midang. Udim kalu sembayang tu selalu bedoa mangke di enjuk anak

Beberapa tahun menikah, berbagai upaya yang dilakukan untuk mndapatkan anak, mulai berobat tradisional maupun medis dan sekarang hanya ada hanya berharap saja, kemudian kalau kakak dengan ayuk ni dek hobi jalan-jalan, jadi disaat stress kami suka jalan-jalan, terkadang jalanjalan bersama anak tetangga, selain itu dek setiap shalat selalu berdoa agar diberi keturunan 


\section{Pasangan Hendri dan Yela}

Selain shalat, biasenye kalu dang dimak, gale pehasean tu dek, ape dang stress tu, kalu ayuk ni galak cerite nga salah satu keluarge ayuk, soalnye die dulu lame pule mangke ade anak, jadi kalu udim cerite dengan die $t$ lebih nyambung $b$ soalnye die ade pengalaman masalab luk itu, kalu kakak biasenye die galak mancing ape die main bola kaki.

Selain shalat, biasanya disaat lagi stress, kalau ayuk suka curhat dengan salah satu keluarga ayuk, soalnya ia lama juga mendapatkan keturunan, jadi kalau bercerita dengan dia lebih nyambung karena memiliki pengalaman masalah anak, kalau kalau suami biasanya memancing dan bermain sepak bola

Pasangan Marwadi dan Sri

selain selalu mendekatkah dibi nga sang pencipta, misalnye ade ape-ape di komunikasikah nga kakak ni, udim tu fokus b nga usaha yang di lakukah, ame upaya untuk dapatkah anak ni lah program ke dokter anye belum berbasil, tpi masib kah usaha tulah

Senada yang di ungkapkan oleh pasangan Riswandi dan Suhaini. Selain selalu mendekatkan diri kepada sang pencipta, segala sesuatu yang terjadi dikomunikasikan dengan pasangan, kemudian fokus dengan usaha yang dilakukan, kalau upaya untuk mendapatkan anak sudah program dengan dokter tapi belum berhasil, akan tetapi suatu saat nanti akan dicoba lagi." Senada yang diungkapkan oleh pasangan Riswandi dan Suhaini.

Pernyataan di atas diperkuat oleh Maliah tetangga pasangan Marwadi dan Sri:

sepengetahuan saya berbagai upaya yang dilakukan oleh pasangan ini, akan tetapi belum membuabkan hasil, hal tersebut tidah menjadikan mereka patah semangat, karena terlihat dari upaya yang dilakukan mereka

Pasangan Ridhi dan Pely

biasenye upaya yang kami lakukah kalu dang cemas ape dang khawatir tu galak meyakinkah dibi babwe setiap manusie tu pasti ade gale masalahnye dan juge harus percaye Allah tu dide kah ngenjuk kite masalah ame kite dide mampu ngadapinye, udim tu ngikuti kegiatan-kgiatan yang positif luluk lbih rutin ngikuti pengajian, shalat jamaah nga santri, ngajar ngaji, pokoknye ame dang ngumpul nga santri tu tehase tenang juge pehasean, yang tepenting tu selalu mendekatkah dibi nga Allah SWT

Biasanya upaya yang kami lakukan kalau sedang cemas atau khawatir, selalu meyakinkan diri bahwa setiap manusia mempunyai masalah dan juga harus percaya bahwa Allah tidak akan memberikan beban kepada umatnya di luar batas dan kemampuannya, kemudian sering mengikuti kegiatan-kegiatan yang positif, seperti lebih rutin mengikuti pengajian, shalat berjamaah dengan santri, mengajar ngaji, yang terpenting selalu mendekatkan diri kepada kepada Allah SWT

Dari hasil wawancara di atas dapat disimpulkan bahwa beberapa upaya yang dilakukan pasangan yang belum memiliki anak di Kecamtan Kikim Timur dalam hal mengatasi masalah psikologis adalah dengan cara selalu mendekatkan diri kepada Allah, meyakinkan diri bahwa setiap manusia mempunyai masalah dan Allah tidak akan memberikan beban kepada hambanya melebihi batas kemampuannya, kemudian melakukan kegiatan yang positif, seperti mengikuti 
kegiatan keagamaan, lebih rutin mengikuti pengajian, melakukan kegitan yang disukai dan juga selalu berusaha dan berdoa.

\section{DISKUSI}

Berdasarkan observasi, wawancara, dan telaah dokumentasi selanjutnya akan dianalisis terhadap hasil penelitian. Dalam menganalisis hasil penelitian, peneliti akan menginterpretasikan hasil wawancara dengan beberapa informan tentang dinamika psikologis pasangan suami istri yang belum memiliki anak, kemudian membandingkan serta menganalisa berdasarkan teori yang ada pada kajian teori.

\section{Dinamika Psikologis Dilihat Dari Aspek-Aspek Psikologis}

Dinamika psikologis dapat dipahami sebagai suatu tenaga kekuatan yang terjadi pada diri manusia yang mempengaruhi mental dan psikisnya untuk mengalami perkembangan dan perubahan dalam tingkah lakunya sehari-hari baik itu dalam pikirannya, perasaannya maupun perbuatannya (Walgito, 2010). Berdasarkan teori tersebut ditemukan keserasian antara teori dengan penemuan di lapangan yang menunjukkan bahwa dinamika psikologis yang terjadi pada beberapa pasangan suami isteri mengalami perubahan dilihat dari awal pernikahan, pasangan suami istri merasa tidak memiliki anak belum menjadi beban pikiran bagi mereka. Namun dengan seiring berjalannya waktu hal tersebut membuat mereka merasa cemas dan khawatir karena belum memilki keturunan, ditambah lagi beberapa dari mereka mendapatkan tekanan dari pertanyaan yang berkaitan dengan masalah keturunan dan beberapa dari mereka juga sudah melakukan upaya, namun baik dari segi medis maupun upaya pasangan suami istri yang lain dari segi pengobatan tradisional. Beberapa pasangan suami istri telah pasrah dengan kondisinya saat ini ada juga yang masih melakukan beberapa usaha untuk memiliki keturunan.

Dalam hal ini peneliti menganalisis dinamika psikologis berdasarkan aspek-aspek psikologis berikut:

\section{a. Aspek Emosi atau Perasaan}

Berkaitan dengan hal ini, berdasarkan penemuan di lapangan bahwasannya emosi atau perasaan lebih kepada adanya suatu kegelisaan, kekhawatiran dan kecemasan yang dirasakan oleh pasangan suami istri, yang disebabkan oleh banyaknya pertanyaan maupun sikap orang lain yang mempertanyakan seputaran keturunan serta pengontrolan diri terhadap konflik yang terjadi baik dalam diri maupun lingkungan. Berdasarkan penemuan tersebut ditemukan keserasian antara penemuan di lapangan dengan teori yang menunjukkan bahwa perasaan lebih erat hubungannya dengan pribadi seseorang dan berhubungan pula dengan gejala-gejala jiwa yang lain. Oleh sebab itu, tanggapan perasaan seseorang terhadap sesuatu tidak sama dengan tanggapan perasaan orang 
lain terhadap perasaan yang sama (Ahmadi, 2009). Adapun salah satu bentuk dari emosi itu kecemasan, yang mana Muchlas mendefinisikan istilah kecemasan sebagai sesuatu pengalaman subjektif mengenai ketegangan mental kesukaran dan tekanan yang menyertai konflik atau ancaman (Ghufron \& Risnawati, 2016). Secara umum faktor-faktor yang menyebabkan timbulnya kecemasan adalah faktor internal dan faktor eksternal, faktor internal meliputi tingkat religiusitas yang rendah, rasa pesimis, takut gagal, pengalaman negatif masa lalu, dan pikiran yang tidak rasional.Sementara faktor eksternal seperti kurangnya dukungan sosial (Ghufron dan Risnawati, 2016).

\section{b. Aspek Penyesuaian Diri}

Berdasarkan penemuan di lapangan beberapa pasangan menyesuaikan diri dengan lingkungan keluarga, teman maupun tetangga yang telah memiliki keturunan, ada beberapa pasangan suami isteri mudah dalam menyesuaikan diri bahkan menganggap anak keluarga, teman maupun tetangga seperti anak sendiri, namun ada juga beberapa pasutri yang memilih menyesuaikan diri dengan menciptakan sikap biasa saja dan tidak ingin mengambil pusing dengan lingkungan yang telah memiliki anak.

Berdasarkan penemuan tersebut ditemukan keserasian antara penemuan di lapangan dengan teori yang menunjukkan bahwa penyesuaian (adjustment) dipahami sebagai mengubah lingkungan agar menjadi lebih sesuai dengan diri individu. Pengertian ini lebih menekankan pada perubahan lingkungan yang dilakukan oleh individu sehingga tetap sesuai dengan dirinya (Siswato, 2007), karena pasangan suami istri yang telah menikah harus memiliki keterampilan penyesuaian diri dengan pasangannya agar rumah tangga yang dibina bisa mencapai kebahagiaan (Juliawati, 2018).

\section{c. Aspek Motivasi}

Berkaitan mengenai hal ini pasangan suami istri yang belum memiliki anak di Kecamatan Kikim Timur mendapatkan semangat, dukungan dan saran dari orang-orang terdekat seperti keluarga, tetangga, teman dekat maupun pasangan satu sama lain, sehingga sebagian dari pasangan suami istri masih ada keyakinan bahwa suatu saat nanti akan memiliki keturunan, akan tetapi ada juga pasangan yang tidak ada lagi motivasi dan sudah merasa pasrah. Motivasi menikah harus dibanahi bagi pasangan suami istri yang menikah agar terhindar dari stress (Retnowati, \& Pujiastuti, 2004)

Berdasarkan penemuan tersebut ditemukan keserasian antara penemuan di lapangan dengan teori yang menunjukkan bahwa Menurut Najati (dalam Shaleh, 2004), motivasi adalah 
kekuatan penggerak yang membangkitkan aktivitas pada makhluk hidup, dan menimbulkan tingkah laku serta mengarahkannya menuju tujuan tertentu. Motivasi memiliki tiga kompenen pokok, yaitu:

1) Menggerakkan. Dalam hal ini motivasi menimbulkan kekuatan pada individu, membawa seseorang untuk bertindak dengan cara tertentu. Misalnya kekuatan dalam hal ingatan, responrespon efektif, dan kecenderungan mendapatkan kesenangan.

2) Mengarahkan. Berarti motivasi mengarahkan tingkah laku. Dengan demikian ia menyediakan suatu orientasi tujuan. Tingkah laku individu diarahkan terhadap sesuatu.

3) Menopang. Artinya, motivasi digunakan untuk menjaga dan menopang tingkah laku, lingkungan sekitar harus menguatkan intensitas dan arah dorongan-dorongan dan kekuatankekuatan individu.

\section{Upaya yang Dilakukan Pasangan Suami Istri dalam Mengatasi Masalah Psikologis}

Firman Allah SWT dalam Al-Qur'an yang artinya: "Hai orang-orang yang beriman, jadikanlah sabar dan shalat sebagai penolongmu, sesungguhnya Allah beserta orang-orang yang sabar" (QS. Al-Baqarah: 153). Dilema kehidupan akan selalu muncul dalam perjalanan hidup. Dalam menghadapinya tidak setiap orang dapat mengatasinya dengan baik. Perubahan-perubahan sosial yang terlampau cepat yang disertai dengan perubahan nilai moral dan etika kehidupan dapat menggoncangkan keseimbangan suasana hati yang pada gilirannya dapat mengakibatkan ketegangan jiwa atau stress. Maka dari itu mintalah bantuan dari Allah dalam seluruh urusan kalian dengan bersabar dalam menghadapi berbagai bala dan musibah, dan bersabar dalam menjalankan ketaatan dan ibadah-ibadah serta amalan yang mendekatkan kepada Allah, dan dengan shalat yang menyebabkan jiwa-jiwa menjadi tentram, serta dapat menahan diri dari perbuatan keji dan munkar. Sesungguhnya Allah bersama orang-orang yang bersabar dengan pertolongan Nya, Taufik dan tuntunan Nya kepada jalan yang lurus. Salah satu pendekatan yang bisa digunakan untuk mengatasi masalah psikologis yaitu dengan pendekatan Tazkiyatun An-Nafs yang merupakan manisfestasi pikiran dan hati yang mendalam untuk membantu membentuk emosi positif dan melepaskan yang negatif (Faiz, dkk., 2019). Selain itu, juga bisa digunakan terapi reframing dalam usaha membingkai ulang pengalaman psikologis yang negatif menjadi positif (Yandri, dkk., 2018).

Selain itu, pendekatan logoteraphy juga bisa dimanfaatkan untuk mengentaskan masalah psikologis karena pendekatan ini ada hakikanya disamping mengarahkan klien untuk mengambil hikmah dari setiap masalah yang menimpanya, juga mengarahkan klien untuk berpikir positif 
(Pasmawati, 2015). Beberapa petunjuk yang dapat diamalkan dalam upaya meningkatkan kekebalan terhadap berbagai problema kehidupan sehari-hari (Hawari, 1996) yaitu sebagai berikut:

a. Makanan

Makanlah secara teratur, usahakan jangan sampai terlambat, makanlah sedang-sedang saja jangan berlebihan sampai kegemukan, atau sebaliknya jangan sampai kurang hingga kekurangan gizi. Berhentilah makan sebelum merasa terlalu kenyang.

b. Olahraga

Untuk meningkatkan daya tahan dan kekebalan baik fisik maupun mental, olahraga adalah salah satu caranya, setidaknya dua kali seminggu bergerak badan hingga berkeringat.Mandilah dngan air hangat.

c. Agama

Dalam memeluk suatu agama, hendaknya tidak saja secara formal memeluknya, tetapi hendaknya menghayati dan mengamalkannya, sehingga memperoleh kekuatan dan ketenangandaripadanya. Usahakan setiap hari menyempatkan waktu untuk mencari ketenangan diri dengan shalat dan berdoa.Memohon ampunan dan petunjuk kepada Allah SWT.

d. Rekreasi

Guna membebaskan diri dari kejenuhan pekerjaan atau kehidupan yang menonton, maka meluangkan waktu untuk rekreasi atau mencari hiburan (hiburan yang shat tentunya) amatlah baik guna untuk memulihkan ketahanan fisik maupun mental. Hadirilah berbagai kegiatan atau acara dari klub atau pergaulan sosial.

e. Kasih sayang

Dari segi kejiwaan, soal kasih sayang adalah yang amat fundamental bagi kesehatan jiwa seseorang.Usahakan secara teratur menerima dan memberikan kasih sayang.

f. Psikoterapi keagamaan

Memberikan psikoterapi dari sudut keagamaan dapat dianjurkan bahwa dalam agama islam misalnya dapat ditemukan ayat-ayat suci Al-Qur'an, hadis Nabi dan pemikiran-pemikiran islam yang mengandung tuntunan bagaimana dalam kehidupan di dunia ini manusia bebas dari rasa cemas, depresi dan lain sebagainya. Demikian pula dapat ditemukan dalam doa-doa yang pada intinya memohon kepada Allah SWT agar dalam kehidupan ini manusia diberi ketenangan, kesejahteraan dan keselamatan baik di dunia maupun kelak di akhirat.

Berdasarkan teori tersebut ditemukan keserasian antara teori dengan penemuan di lapangan yang menunjukkan bahwa upaya yang dilakukan oleh pasangan suami istri yang belum memiliki anak di kecamatan Kikim Timur, dengan meyakinkan diri bahwa setiap manusia memiliki 
masalah, dan sang pencipta tidak akan memberikan beban kepada hambanya di luar kemampuannya, ada yang melakukan kegiatan keagamaan, ada juga dengan melakukan kegiatan yang disenangi bisa dikatakan hobi seperti olahraga, rekreasi dan melakukan berbagai pengobatan baik secara medis maupun herbal.

\section{KESIMPULAN}

Simpulan dari penelitian ini yaitu sebagai berikut:

\section{Dinamika Psikologis Pasangan Suami Istri yang Belum Memiliki Anak}

Dinamika psikologis yang terjadi pada beberapa pasangan suami istri yang belum memiliki anak di Kecamatan Kikim Timur, Kabupaten Lahat, Provinsi Sumatera Selatan berdasarkan aspek, emosi, penyesuain diri dan motivasi. Dilihat dari aspek emosi mengalami perubahan dilihat dari awal pernikahan, pasangan suami istri merasa tidak memiliki anak belum menjadi beban pikiran bagi mereka. Namun dengan seiring berjalannya waktu hal tersebut membuat mereka merasa cemas dan khawatir karena belum memilki keturunan, bahkan karena sudah berpuluh-puluh tahun menikah belum juga memiliki keturunan mereka merasa pasrah.Kemudian dari aspek penyesuaian diri sebagian pasangan suami istri ada yang mudah dalam berinteraksi dengan keluarga yang sudah memiliki anak, sebaliknya ada juga yang merasa kesulitan dan minder dalam menyesuiakan diri dengan orang yang sudah memiliki keturunan. Dilihat dari aspek motivasi beberapa pasangan suami istri mendapatkan dukungan atau saran dari keluarga, tetangga dan suami, akantetapi ada juga yang hanya mendapatkan dukungan dan saran dari suami dan hanya sebagian dari keluarga. Namun yang paling mempengaruh pasangan suami istri yang belum memiliki anak di Kecamatan Kikim Timur itu aspek emosi.

\section{Upaya yang Dilakukan Pasangan Suami Istri dalam Mengatasi Masalah Psikologis}

Adapun upaya yang dilakukan, melakukan kegiatan-kegiatan yang positif seperti mengikuti kegiatan keagamaan, meyakinkan diri bahwa kondisi ini pasti bisa dilewati kemudian melakukan kegiatan yang disukai seperti olahraga dan rekreasi.Selain itu juga melakukan berbagai upaya pengobatan baik itu secara medis maupun tradisonal atau herbal.

\section{REFERENSI}

Ahmadi, A. (2009). Psikologi Umum. Jakarta: PT Rineka Cipta

Dapartemen Agama. (2006). Mushaf Al-Qur'an Al-Kahfi. Bandung: Diponorogo

Faizah dan Effendi, L. M. (2006). Psikologi Dakwah. Jakarta: Kencana 
Faiz, A., Yandri, H., Kadafi, A., Mulyani, R. R., Nofrita, N., \& Juliawati, D. (2019). Pendekatan Tazkiyatun An-Nafs untuk membantu mengurangi emosi negatif klien. Counsellia: Jurnal Bimbingan dan Konseling, 9(1), 65-78.

Ghufron, N \& Risnawati, R. (2016). Teori-Teori Psikologi. Jogjakarta: Ar-Ruzz Media

Hawari, D. (1996). Al Qur'an: Ilmu Kedokteran Jiwa dan Kesehatan Jiwa. Yogyakarta: Dana Bhakti Prima Yasa

Idrus, M. (2009). Metode Penelitian Ilmu Sosial. Yogyakarta: Erlangga.

Juliawati, D. (2018). Studi Kasus Terhadap Mahasiswa yang Menikah Saat Menempuh Masa Kuliah. Tarbawi: Jurnal Ilmu Pendidikan, 13(2), 43-49.

Mak'shum. Kisah Teladan 25 Nabi dan Rosul. Gresik: Bintang Pelajar.

Munir, S. A dan Al-Hafidzoh, I. (2010). Menanti Sang Buab Hati. Jakarta: Amzah

Pasmawati, H. (2015). Pendekatan Logoteraphy dalam Konseling. Jurnal Ilmiah Syíar, 15(1), 53-64.

Retnowati, S., \& Pujiastuti, E. (2004). Kepuasan pernikahan dengan depresi pada kelompok wanita menikah yang bekerja dan yang tidak bekerja. Humanitas: Jurnal Psikologi Indonesia, $1(2)$.

Siswanto. (2007). Kesehatan Mental: Konsep, Cakupan, dan Perkembangannya. Yogyakarta: Andi Offset

Sugiyono. (2009). Metode Penelitian Pendidikan (Pendekatan Kuantitatif, Kualitatif dan R\&D). Bandung: Alfabeta

Sugiyono. (2013). Metode Penelitian Kuantitatif, Kualitatif, dan Kombinasi (Mixed Methods). Bandung: Alfabeta

Walgito, B. (2010). Pengantar Psikologi Umum. Yogyakarta: Andi Yogyakarta.

Walgito, B. (2017). Bimbingan dan Konseling Perkawinan. Yogyakarta: Andi Offset.

Yandri, H., Juliawati, D., Alfaiz., \& Nofrita, (2018). Keterampilan Konselor dalam Melepas Emosi Negatif Anak dengan Terapi Reframing. (Proceeding: Seminar Nasional Bimbingan dan Konseling di Perguruan Tinggi, Bandung).

Yandri, H., \& Juliawati, D. (2019). Pelatihan Pembuatan Daftar Check List Deteksi Tumbuh Kembang Anak Usia Dini Berbasis Tauhid bagi Guru TK/PAUD Kota Sungai Penuh. MATAPP A: Jurnal Pengabdian Kepada Masyarakat, 2(2).

Yusuf, A. M. (2014). Metode Penelitian: Kuantitatif, Kualitatif dan Penelitian Gabungan. Jakarta: Prenamedia Group. 